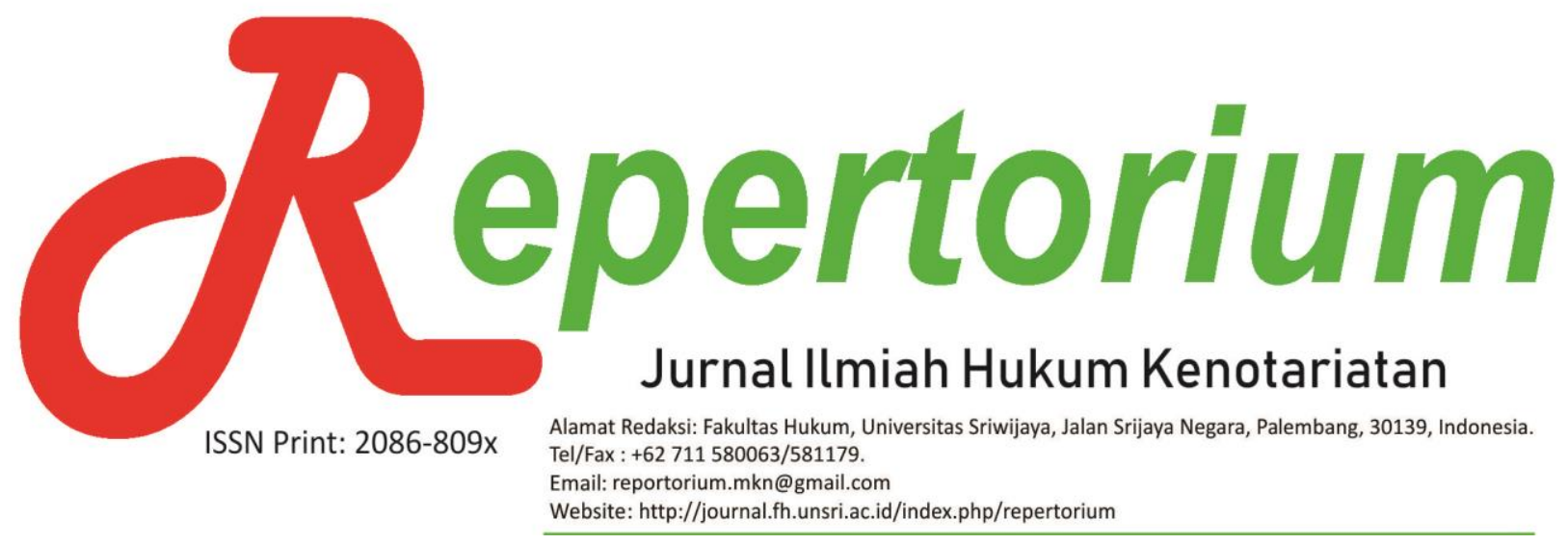

\title{
FUNGSI ITSBAT NIKAH TERHADAP ISTERI YANG DINIKAHI SECARA TIDAK TERCATAT (NIKAH SIRI) APABILA TERJADI PERCERAIAN
}

\author{
Gema Mahardhika Dwiasa* \\ Dr. H. K. N. Sofyan Hasan, S.H, M.H** \\ H. Achmad Syarifudin., S.H.,Sp.N**
}

\begin{abstract}
Abstrak: Pada dasarnya perkawinan merupakan suatu akad yang menyebabkan halalnya hubungan antara seorang laki-laki dan seorang perempuan sebagai suami-isteri. Dalam ikatan perkawinan ditegaskan hak dan kewajiban antara suami-isteri tersebut, sehingga dapat tercapai kehidupan rumah tangga yang sakinah dan sejahtera. Menurut Pasal 1 Undang-Undang Nomor 1 Tahun 1974 tentang Perkawinan menyatakan bahwa perkawinan adalah ikatan lahir bathin seorang pria dengan wanita untuk membentuk keluarga yang kekal berdasarkan Ketuhanan Yang Maha Esa. Perkawinan yang telah dilangsungkan dengan memenuhi ketentuan pasal 2 ayat (1) harus dicatat oleh petugas pencatat perkawinan dengan tujuan untuk tertib administrasi pemerintahan dan kependudukan serta untuk memenuhi ketentuan Undang-Undang Perkawinan. Perkawinan yang dicatatkan merupakan sebagai bentuk perlindungan hukum apabila dikemudian hari terjadi permasalahan dalam sebuah ikatan perkawinan, apabila hal itu tidak dilakukan maka perkawinan yang dilakukan tidak mempunyai kekuatan hukum. Nikah siri atau perkawinan yang tidak tercatat adalah salah satu bentuk dari pemasalahan yang sering terjadi di Indonesia. Banyak faktor yang menyebabkan seseorang tidak mencatatkan pernikahannya di lembaga pencatatan. Ada yang karena faktor biaya, alias tidak mampu membayar administrasi pencatatan sehingga tidak dicatatkan tetapi tidak dirahasiakan; belum cukup umur untuk melakukan perkawinan secara negara; ada pula yang disebabkan karena takut ketahuan melanggar aturan yang melarang pegawai negeri nikah lebih dari satu; dan lain sebagainya. Ada juga, pernikahan yang dirahasiakan karena pertimbangan-pertimbangan tertentu; misalnya karena takut mendapatkan stigma negatif dari masyarakat yang terlanjur menganggap tabu pernikahan siri; atau karena pertimbangan-pertimbangan rumit yang memaksa seseorang untuk merahasiakan pernikahannya. Pada saat timbul masalah memerlukan akta nikah sebagai bukti autentik baik untuk perceraian maupun keperluan lainnya maka harus mengajukan permohonan itsbat nikah ke Pengadilan Agama. Kurangnya pengetahuan masyarakat tentang adanya Itsbat Nikah menjadi salah satu fakor penghambat terlaksananya perlindungan hukum terhadap isteri yang dinikahi dari perkawinan yang tidak tercatat.
\end{abstract}

Kata Kunci : Itsbat Nikah; Perlindungan Hukum; Perkawinan tidak tercatat; Perceraian; Suami isteri. 

* Magister Kenotariatan Fakultas Hukum Universitas Sriwijaya

** Dosen Magister Kenotariatan Fakultas Hukum Universitas Sriwijaya

\section{LATAR BELAKANG}

Pelaksanaan perkawinan di Indonesia selalu bervariasi bentuknya. Mulai dari perkawinan lewat Kantor Urusan Agama (KUA), perkawinan bawa lari, sampai perkawinan yang populer dikalangan masyarakat, yaitu nikah siri. Perkawinan yang tidak dicatatkan atau yang dikenal dengan berbagai istilah lain seperti 'kawin bawah tangan', 'nikah siri' atau 'nikah sirri', adalah perkawinan yang dilakukan berdasarkan aturan agama atau adat istiadat dan tidak dicatatkan di kantor pegawai pencatat nikah (KUA bagi yang beragama Islam, Kantor Catatan Sipil bagi nonIslam). Istilah siri berasal dari bahasa arab sirra, israr yang berarti rahasia. Nikah siri, menurut arti katanya, perkawinan yang dilakukan dengan sembunyi-sembunyi atau rahasia. Dengan kata lain, perkawinan itu tidak disaksikan orang banyak dan tidak dilakukan di hadapan pegawai pencatat nikah. Perkawinan itu dianggap sah menurut agama tetapi melanggar ketentuan pemerintah.

Sementara definisi perkawinan yang ada pada Undang-Undang Nomor 1 Tahun 1974 tentang Perkawinan, selanjutnya disingkat UUP, menyatakan bahwa perkawinan tidak lagi hanya dilihat sebagai hubungan jasmani saja tetapi juga merupakan hubungan batin. Selain itu, dalam UUP tujuan perkawinan dieksplisitkan dengan kata bahagia. Hal ini menunjukkan bahwa pada akhirnya perkawinan dimaksudkan untuk setiap manusia baik laki-laki ataupun perempuan dapat memperoleh kebahagiaan.

Syarat sahnya suatu perkawinan diatur dalam Pasal 2 ayat (1) UUP, yang menyebutkan :

"Perkawinan adalah sah apabila dilakukan menurut hukum masing-masing agama dan kepercayaannya"

Makna perumusan dari Pasal 2 ayat (1) tersebut, tidak ada perkawinan diluar hukum masing-masing agamanya dan kepercayaannya itu, sesuai dengan UndangUndang Dasar 1945. Yang dimaksud hukum masing-masing agamanya dan kepercayaanya itu sepanjang tidak bertentangan atau tidak ditentukan lain dalam Undang-Undang itu.

Untuk pasangan yang beragama Islam syarat sahnya perkawinan dipertegas lagi dalam Instruksi Presiden Republik Indonesia Nomor 1 Tahun 1991 tentang Kompilasi Hukum Islam, selanjutnya disingkat KHI, Pasal 4 yaitu :

"Perkawinan adalah sah apabila dilakukan menurut Hukum Islam sesuai dengan Pasal 2 ayat (1) UUP'

Perkawinan yang telah dilangsungkan dengan memenuhi ketentuan Pasal 2 ayat (1) harus dicatat oleh petugas pencatat perkawinan dengan tujuan untuk tertib administrasi pemerintahan dan kependudukan serta untuk memenuhi ketentuan dari Pasal 2 ayat (2) UUP.

Perkawinan yang dicatatkan merupakan sebagai bentuk perlindungan hukum apabila dikemudian hari terjadi 

permasalahan dalam sebuah ikatan perkawinan, apabila hal itu tidak dilakukan maka perkawinan yang dilakukan tidak mempunyai kekuatan hukum.

Faktor yang menyebabkan seseorang tidak mencatatkan pernikahannya dilembaga pencatatan. Ada yang karena faktor biaya, alias tidak mampu membayar administrasi pencatatan sehingga tidak dicatatkan tetapi tidak dirahasiakan; belum cukup umur untuk melakukan perkawinan secara negara; ada pula yang disebabkan karena takut ketahuan melanggar aturan yang melarang pegawai negeri nikah lebih dari satu; dan lain sebagainya. Ada juga, pernikahan yang dirahasiakan karena pertimbangan-pertimbangan tertentu; misalnya karena takut mendapatkan stigma negative dari masyarakat yang terlanjur menganggap tabu pernikahan siri.

Dengan adanya pencatatan perkawinan yang dibuktikan dengan Akta Nikah selain untuk mentaati ketertiban administrasi negara juga sebagai pembuktian yang memiliki kekuatan hukum. Akta nikah merupakan akta autentik karena dibuat oleh dan dihadapan Pegawai Pencatat Nikah sebagai pejabat yang berwenang untuk melakukan pencatatan perkawinan, dibuat sesuai dengan bentuk yang ditetapkan oleh Peraturan Pemerintah Nomor 9 Tahun 1975 dan dibuat ditempat Pegawai Pencatat Nikah/Kantor Urusan Agama melaksanakan tugasnya.

Permasalahan yang dibahas dalam penelitian ini dapat dirumuskan sebagai berikut : Pertama, Bagaimana fungsi itsbat nikah dalam memberi perlindungan hukum terhadap isteri yang dinikahi secara tidak tercatat (nikah siri) apabila terjadi perceraian?. Kedua, 2.Faktor-faktor apa saja yang menghambat proses dikabulkannya itsbat nikah dalam kasus perceraian dari perkawinan yang tidak tercatat (nikah siri)?

\section{Metode}

Penelitian yang akan dilakukan merupakan tipe penelitian hhukum normatif/doctrinal dan empiris/non-doktrinal benar-benar berbeda atau dapat diharmonisasikan dalam suatu kegiatan penelitian hukum. penelitian hukum doctrinal, yaitu penelitian yang objek kajiannya tentang dokumen. Bahanbahan tersebut disusun secara sistematis, dikaji kemudian ditarik suatu kesimpulan dalam hubungannya dengan masalah yang diteliti sedangkan penelitian hukum empiris dimaksudkan untuk mengajak para penelitinya tidak hanya memikirkan masalah-masalah hukum yang bersifat normatif (law as written in book), bersifat teknis di dalam mengoperasionalisasikan peraturan hukum seperti mesin yang memproduksi dan menghasilkan hasil tertentu dari sebuah proses mekanis, dan tentunya hanya dan harus bersifat preskriptif namun di dalam konteks ini lebih dimaksudkan kepada pengertian bahwa "kebenarannya dapat dibuktikan pada alam kenyataan atau dapat dirasakan oleh panca indera.

Bahan hukum primer yang digunakan yaitu bahan yang mempunyai kekuatan mengikat, yang bersumber dari peraturan perundang-undangan yang berkaitan dengan masalah yang diteliti, yang terdiri dari:

1. Hukum Islam ( Hukum Perkawinan Islam)

2. UUP 



\section{3. $\mathrm{KHI}$}

Bahan hukum skunder yaitu bahan hukum yang menjelaskan mengenai bahan hukum primer Kitab Undang-Undang Hukum Perdata, Peraturan Perundangan dan Peraturan Pemerintah yang berkaitan dengan pelaksanaan Hukum Perkawinan di Indonesia. Buku-buku, literatur, artikel, makalah, dan tulisan-tulisan yang berkaitan dengan Perkawinan Siri dan wawancara (interview). Bahan hukum tersier yaitu bahan hukum yang memberikan petunjuk maupun penjelasan terhadap bahan hukum primer dan skunder seperti ensiklopedi, kamus, jurnal hukum, media massa, dan lain-lain, sebagai penunjang.

\section{ANALISIS DAN DISKUSI}

Dalam UUP tersebut sahnya perkawinan yang menjadi permasalahan pada Rancangan Undang-Undang Pasal 2 diubah menjadi sebagai berikut: ${ }^{1}$

1. Perkawinan adalah sah, apabila dilakukan menurut hukum masingmasing agamanya dan kepercayaannya itu.

2. Tiap-tiap perkawinan dicatat menurut Peraturan Perundang-Undangan yang berlaku.

Demi terlaksananya UndangUndang tersebut maka pemerintah mengeluarkan Peraturan Pemerintah Nomor 9 Tahun 1975 sebagai peraturan pelaksana dari UUP tersebut. Pada tahun-tahun berikutnya ternyata Pengadilan Agama sebagai lembaga yuridis yang menangani masalah perkawinan antara orang-orang

\footnotetext{
${ }^{1}$ Nawawi Muhammad. Sejarah Hukum Perkawinan di Indonesia Pendahuluan http://www.academia.edu/3797838/SEJARAH_HU KUM_PERKAWINAN_DI_INDONESIA_PENDA HULUAN . 13 Februari 2018.
}

Islam ternyata dalam putusannya banyak yang disparitas dalam menerapkan hukum, karena adanya hal-hal yang tidak dilindungi oleh UUP dan Peraturan Pemerintah mengenai pelaksanannya. Untuk mengatasi hal tersebut maka melalui Inpres Nomor 1 Tahun 1991 tentang pemberlakuan KHI sebagai acuan bagi para Hakim Peradilan Agama dalam memutus suatu perkara. ${ }^{2}$

Lahirnya UUP dan peraturanperaturan lain yang mengatur tentang perkawinan sejauh telah diatur dalam UUP tidak diberlakukan lagi, hal tersebut berdasarkan bunyi Pasal 66 UUP yaitu: ${ }^{3}$

"Untuk perkawinan dan segala sesuatu yang berhubungan dengan perkawinan berdasarkan atas Undang-Undang ini, maka dengan berlakunya Undang-Undang ini ketentuan-ketentuan yang diatur dalam Kitab Undang-Undang Hukum Perdata (Burgerlijke Wetboek), Ordonansi Perkawinan Indonesia Kristen (Huwelijks Ordonantie Christen Indonesiaers, S. 1933 No.74)", Peraturan Perkawinan Campuran (Regeling op de gemeng de Huwelijiken S. 1898 Nom. 158) dan Peraturan-peraturan lain yang mengatur tentang perkawinan sejauh telah diatur dalam Undang-Undang ini, dinyatakan tidak berlaku."

Kawin menurut pengertian asli ialah hubungan seksual tetapi menurut arti majazi atau arti hukum ialah aqad atau perjanjian yang menjadikan halal hubungan seksual sebagai suami isteri antara seorang pria

\footnotetext{
${ }^{2}$ Ibid.

3 Undang-Undang Republik Indonesia Nomor 1 Tahun 1974 Tentang Perkawinan. (Lembaran Negara Republilk Indonesia Tahun 1974 Nomor 1. tambahan Lembaran Negara Nomor 3019). Pasal 66.
} 

dengan seorang wanita. $^{4}$ Pengertian perkawinan dalam hal ini bisa ditinjau dari dua sudut pandang yaitu menurut hukum Islam dan menurut UUP dan KHI.

$$
\text { KHI menjelaskan tujuan }
$$
perkawinan dalam Pasal 3 yaitu: ${ }^{5}$

"Perkawinan bertujuan untuk mewujudkan rumah tangga sakinah mawaddah dan warahmah"

Mengenai perkawinan yang sah, menurut Pasal 4 KHI yaitu:

"Perkawinan adalah sah, apabila dilakukan menurut hukum Islam sesuai dengan Pasal 2 ayat (1) UUP"

Artinya KHI lebih menekankan perkawinan dalam konsep hukum Islam, namun tetap didasarkan pada UUP. Landasan hukum pembentukan KHI adalah Pasal 27 UU No. 14 Tahun 1970 tentang Kekuasaan Kehakiman yang berbunyi: "Hakim sebagai penegak hukum dan keadilan wajib menggali, mengikuti dan memahami nilai-nilai hukum yang hidup dalam masyarakat. Sedangkan landasan fungsional KHI adalah fiqih Indonesia yang disusun dengan memerhatikan kondisi kebutuhan umat Islam Indonesia. Bukan mazhab baru tetapi mengarah kepada penhyatuan berbagai pendapat mazhab hukum Islam untuk menyatukan persepsi para hakim tentang hukum Islam. Untuk menuju kepastian hukum umat Islam. $^{6}$ Tujuan pembentukan KHI yaitu sebagai berikut: ${ }^{7}$

\footnotetext{
4 Moh. Idris Ramulyo.2002. Hukum Perkawinan Islam. Suatu Analisis Dari UUP Dan KHI. Jakarta : Bumi Aksara. hlm.1.

5 Instruksi Presiden Nomor 1 Tahun 1991 (Kompilasi Hukum Islam). Pasal 3.

6 Muchsin. 2004. Masa Depan Hukum Islam di Indonesia. Jakarta : BP IBLAM. hlm.45-46.

7 M. Yahya Harahap. 1999. Informasi Materiil Kompilasi Hukum Islam : Memposisikan Abstraksi Hukum Islam dalam Cik Hasan Basri (Ed).
}
a. Melengkapi Pilar Peradilan Agama;
b. Menyamakan Persepsi Penerapan Hukum;
c. Mempercepat Proses Taqribi Bainal Ummah;
d. Menyingkirkan Paham Private Affairs.

Perkawinan siri merupakan perkawinan yang hanya mendasar pada hukum Islam saja, tanpa mengindahkan peraturan hukum nasional Indonesia. Kata siri berasal dari bahasa Arab yaitu Sirri atau Sir yang berarti rahasia. Rahasia dalam hal ini merujuk pada rukun Islam mengenai perkawinan yang berbunyi perkawinan yang sah apabila diketahui orang banyak.

Perkawinan siri merupakan perkawinan yang hanya mendasar pada hukum Islam saja, tanpa mengindahkan peraturan hukum nasional Indonesia. Kata siri berasal dari bahasa Arab yaitu Sirri atau Sir yang berarti rahasia. Rahasia dalam hal ini merujuk pada rukun Islam mengenai perkawinan yang berbunyi perkawinan yang sah apabila diketahui orang banyak.

Nikah siri adalah perkawinan yang dilakukan dengan adanya wali dan dua orang saksi yang adil serta adanya ijab qabul, hanya saja perkawinan ini tidak dicatatkan dalam Lembaga Pencatatan Negara, dalam hal ini adalah Kantor Urusan Agama. Perkawinan seperti ini yang dinyatakan sebagai nikah siri atau perkawinan yang tidak tercatat.

Latar belakang nikah siri adalah tidak mampu mengeluarkan dana untuk mendaftarkan diri ke KUA yang dianggap begitu mahal. ${ }^{8}$ Atau walaupun secara

Kompilasi Hukum Islam dan Peradilan Agama Dalam Sistem Hukum Nasional. Jakarta : Logos. hlm.27.

${ }^{8}$ Ibid. 

finansial pasangan ini cukup membiayai, namun karena khawatir pernikahannya tersebar luas KHInya mengurungkan niatnya mendaftar secara resmi ke KUA atau catatan sipil. ${ }^{9}$ Hal ini untuk menghilangkan jejak dan bebas dari tuntutan hukum dan hukuman administrasi dari atasan, terutama untuk perkawinan kedua dan seterusnya (bagi pegawai negeri dan TNI). ${ }^{10}$

Faktor lain, ada kecenderungan mencari celah-celah hukum yang tidak direpotkan oleh berbagai prosedur pernikahan yang dinilai berbelit, yang penting dapat memenuhi tujuan, sekalipun harus rela mengeluarkan uang lebih banyak dari seharusnya. ${ }^{11}$ UUP beserta peraturan pelaksanaannya mengatur syarat yang cukup ketat bagi seseorang atau pegawai negeri sipil (PNS) yang akan melangsungkan untuk kali kedua dan seterusnya, atau yang akan melakukan perceraian. ${ }^{12}$ Syarat yang ketat seperti itu, bagi sebagian orang dijadikan peluang "bisnis" yang cukup menjanjikan, yaitu dengan menawarkan berbagai kemudahan dan fasilitas dari hanya sekedar menikahkan secara siri sampai membuatkan akta nikah asli tapi palsu.

Walaupun pada dasarnya perkawinan itu bertujuan untuk selamalamanya, tetapi adakalanya ada sebab-sebab tertentu yang mengakibatkan perkawinan tidak dapat diteruskan jadi harus di putuskan di tengah jalan atau terpaksa putus

\footnotetext{
${ }^{9}$ Ibid.hlm.12.

${ }^{10}$ Ibid.

11 Ibid.

${ }^{12}$ Ibid.
}

dengan sendirinya, atau dengan kata lain terjadi perceraian antara suami dan isteri. ${ }^{13}$

Di dalam KHI Pasal 113 disebutkan bahwa perkawinan dapat putus karena kematian, perceraian dan atas putusan Pengadilan. ${ }^{14}$ Putusnya perkawinan karena kematian salah satu pihak dari suami atau isteri maksudnya adalah apabila salah seorang dari kedua suami isteri itu meninggal dunia, maka perkawinannya putus karena adanya kematian tersebut. Atau perkawinan terhapus jikalau salah satu pihak meninggal. ${ }^{15}$

Putusnya perkawinan karena perceraian antara suami isteri maksudnya apabila suami isteri itu bercerai, maka perkawinannya putus karena adanya perceraian tersebut. Perceraian ini dapat terjadi langsungatau dengan tempo dengan menggunakan kata talaq atau kata lain yang senada, putusnya perkawinan yang disebabkan karena perceraian dapat terjadi karena talaq atau berdasarkan gugatan perceraian, sebagaimana bunyi pasal 114 KHI. ${ }^{16}$ Sedangkan putusnya perkawinan atas putusan Pengadilan dapat terjadi karena pembatalan perkawinan.

Menurut Pasal 116 KHI, perceraian dapat terjadi karena: ${ }^{17}$

a) Salah satu pihak berbuat zina atau menjadi pemabuk, pemadat, penjudi dan lain sebagainya yang sukar disembuhkan;

b) Salah satu pihak meninggalkan pihak lain selama 2 (dua) tahun

\footnotetext{
${ }^{13}$ Soemiyati. 1997. Hukum Perkawinan Islam dan Undang-Undang Perkawinan. Yogyakarta: Liberty. hlm.105.

${ }^{14}$ Lihat Pasal 113 Kompilasi Hukum Islam.

15 Subekti. 1996. Pokok-Pokok Hukum Perdata. Jakarta: PT. Intermassa. hlm.42.

${ }^{16}$ Lihat Pasal 114 Kompilasi Hukum Islam.

${ }^{17}$ Lihat Pasal 116 Kompilasi Hukum Islam.
} 

berturut-turut tanpa izin pihak lain dan tanpa alasan yang sah atau karena hal lain di luar kemampuannya;

c) Salah satu pihak mendapat hukuman penjara 5 (lima) tahun atau hukuman yang lebih berat setelah perkawinan berlangsung;

d) Salah satu pihak melakukan kekejaman atau penganiayaan berat yang membahayakan pihak yang lain;

e) Salah satu pihak mendapatkan cacat badan atau penyakit dengan akibat tidak dapat menjalankan kewajibannya sebagai suami atau isteri;

f) Antara suami dan isteri terus menerus terjadi perselisihan dan pertengkaran dan tidak ada harapan akan hidup rukun lagi dalam rumah tangga;

g) Suami melanggar taklik talak;

h) Peralihan agama atau murtad yang menyebabkan terjadinya ketidakrukunan dalam rumah tangga.

Memperhatikan substansi diatas, maka dapat ditegaskan bahwa perceraian mempunyai akibat hukum terhadap anak dan mantan suami isteri. Selain itu perceraian juga mempunyai akibat hukum terhadap harta bersama sebagaimana diatur dalam Pasal 37 UUP yang memuat ketentuan bahwa akibat hukum terhadap harta bersama diatur menurut hukum agama, hukum adat atau hukum yang lain. Jika dicermati esensi dari akibat-akibat hukum percerain yang diatur dalam UUP adalah mengakui dan melindungi hak-hak anak dan hak-hak mantan suami/isteri sebagai Hak-hak Asasi Manusia (HAM). ${ }^{18}$

Itsbat nikah adalah sebuah proses Pencatatan Nikah terhadap nikah siri yang dilakukan, untuk mendapatkan akta nikah sebagai bukti keabsahan dari perkawinan yang telah dilakukan, seperti yang dijelaskan dalam UUP Pasal 2 ayat (1) bahwa perkawinan adalah sah apabila dilakukan menurut hukum Islam, serta dijelaskan pula dalam Pasal 2 ayat (2) bahwa tiap-tiap perkawinan dicatat menurut Peraturan Perundang-Undangan yang berlaku.

Pencatatan perkawinan dalam pelaksanaannya diatur dengan PP Nomor 9 Tahun 1975 dan Peraturan Menteri Agama Nomor 3 dan 4 Tahun 1975 Bab II Pasal 2 ayat (1) PP Nomor 9 Tahun 1975, pencatatan perkawinan dari mereka yang melangsungkannya menurut Agama Islam dilakukan oleh pegawai pencatat, sebagaimana dimaksud dalam UndangUndang Nomor 3 Tahun 1954 tentang Pencatatan Nikah, Talak dan Rujuk.

Menurut Ahmad Musa Hasibuan, selaku Hakim Pengadilan Agama Kelas 1 A Palembang itsbat nikah merupakan suatu bentuk perlindungan hukum bagi wanita yang melakukan nikah siri agar mendapat hak-haknya sebagai seorang isteri atau

\footnotetext{
${ }^{18}$ Muhammad Syaifuddin. Sri Turatmiyah. Annalisa Yahanan. 2013. Hukum Perceraian. Jakarta: Sinar Grafika. hlm.349-350.
} 

mantan isteri. $^{19}$ Menurut persepsi dikalangan praktisi hukum, khususnya hakim Pengadilan Agama, bahwa yang dimaksud dengan itsbat nikah merupakan produk hukum declarative sekadar untuk menyatakan sahnya perkawinan yang dilaksanakan menurut hukum agama namun tidak dicatatkan, dengan implikasi hukum setelah perkawinan tersebut diitsbatkan menjadi memiliki kepastian hukum (rechtszekerheid). ${ }^{20}$

Berbeda dengan nikah siri atau dibawah tangan yang hanya dilakukan menurut hukum Fiqih dan nikahnya itu sudah sah secara Fiqih, akan tetapi nikah ini tidak dapat dibuktikan dengan adanya Akta Nikah, oleh karena itu KHI memberi peluang untuk mengajukan permohonan itsbat nikah guna mendapat Akta Nikah sebagai salah satu pembuktian.

Menurut Ahmad Musa Hasibuan, selaku Hakim Pengadilan Agama Kelas I A Palembang kasus mengenai perceraian dari nikah siri bisa diajukan dengan mengajukan 1 (satu) gugatan yang digabungkan menjadi itsbat nikah dan gugat cerai karena gugatan yang di ajukan merupakan bentuk perlindungan yang akan didapatkan oleh isteri untuk mendapatkan keabsahan perkawinannya serta hak-hak yang terdapat pada statusnya. $^{21}$

19 Transkripsi Hasil Wawancara dengan Ahmad Musa Hasibuan. Hakim Pengadilan Agama Kelas I A Palembang. Palembang. Jum'at. 27 April 2018.

20 Endang Ali Ma'sum. Kepastian Hukum Itsbat Nikah. Makalah disampaikan dalam Forum Diskusi Penelitian dilaksanakan oleh Balitbang Diklat Kumdil MA RI. di hotel Le Dian Serang. tanggal 15 Mei 2012. hlm. 4.

${ }^{21}$ Ibid.
Dasar hukum itsbat nikah Di dalam Pasal 7 ayat (1) KHI menerangkan dan menyatakan bahwa: ${ }^{22}$

"Perkawinan hanya dapat dibuktikan dengan Akta Nikah yang dibuat oleh Pegawai Pencatat Nikah"

Ketentuan mengenai isbat nikah terdapat dalam Pasal 7 ayat (2) KHI yang berbunyi: $^{23}$

"Dalam hal perkawinan tidak dapat dibuktikan dengan Akta Nikah, dapat diajukan itsbat nikahnya ke Pengadilan Agama"

Ketentuan dari Pasal 7 ayat (2) KHI tersebut dapat dikatakan bahwa kekuatan hukum dari itsbat nikah tersebut sama dengan kekuatan hukum dari akta nikah sehingga akibat yang hukum yang timbul dari perkawinan yang tidak tercatat yang kemudian di itsbatkan sama dengan perkawinan yang dicatatkan pada saat perkawinan yang dilangsungkan.

Pengesahan nikah diatur dalam Pasal 2 ayat (5) Undang-Undang Nomor 22 Tahun 1946 tentang Pencatatan Nikah Talak dan Rujuk jis Pasal 49 huruf a angka 22 Penjelasan Undang-Undang Nomor 7 Tahun 1989 sebagaimana telah diubah dengan Undang-Undang Nomr 3 Tahun 2006 dan perubahan kedua dengan Undangundang Nomor 50 Tahun 2009. Penjelasan Pasal 49 huruf (a) angka 22.

Pada dasarnya kewenangan perkara itsbat nikah bagi pengadilan agama menurut sejarahnya diperuntukkan bagi mereka yang melakukan perkawinan sebelum berlakunya UUP jo Peraturan Pemerintah tentang

${ }^{22}$ Instruksi Presiden Republik Indonesia Nomor 1 Tahun 1991 (Kompilasi Hukum Islam). Pasal 7 ayat (1).

${ }^{23}$ Instruksi Presiden Republik Indonesia Nomor 1 Tahun 1991 (Kompilasi Hukum Islam). Pasal 7 ayat (2). 

nomor 9 Tahun 1975 penjelasan Pasal 49 ayat 2 yang berbunyi: ${ }^{24}$

"Mulai berlakunya Peraturan Pemerintah ini, merupakan pelaksanaan secara efektif dari UUP"

Serta dalam Pasal 64 UUP yang berbunyi: ${ }^{25}$ "Untuk perkawinan dan segala sesuatu yang berhubungan dengan perkawinan yang terjadi sebelum Undang-Undang ini berlaku yang dijalankan menurut peraturanperaturan lama, adalah sah"

Kemudian kewenangan ini pada akhirnya berkembang dan diperluas dengan dipakainya ketentuan KHI, pada Pasal 7 ayat (2) dan ayat (3). Dalam ayat (2) telah disebutkan : Dalam hal perkawinan tidak dapat dibuktikan dengan Akta Nikah, dapat diajukan itsbat nikahnya ke Pengadilan Agama dan dalam ayat (3) $\mathrm{KHI}^{26}$ yang menyatakan hal yang berkenaan dengan:

"Itsbat nikah yang dapat diajukan ke Pengadilan Agama terbatas mengenai halhal yang berkenaan dengan:

(a) Adanya perkawinan dalam rangka penyelesaian perceraian

(b) Hilangnya Akta Nikah

(c) Adanya keraguan tentang sah atau tidaknya salah satu syarat perkawinan

(d) Adanya perkawinan yang terjadi sebelum berlakunya Undang-Undang No. 1 Tahun 1974

\footnotetext{
24 Undang-Undang Republik Indonesia Nomor 1 Tahun 1974 tentang Perkawinan. (Lembaran Negara Republilk Indonesia Tahun 1974 Nomor 1. tambahan Lembaran Negara Nomor 3019). Pasal 49 ayat (2).

${ }^{25}$ Undang-Undang Republik Indonesia Nomor 1 Tahun 1974 tentang Perkawinan. (Lembaran Negara Republilk Indonesia Tahun 1974 Nomor 1. tambahan Lembaran Negara Nomor 3019). Pasal 64.

${ }^{26}$ Instruksi Presiden Republik Indonesia Nomor 1 Tahun 1991 (Kompilasi Hukum Islam). Pasal 7 ayat (3.)
}

(e) Perkawinan yang dilakukan oleh mereka yang tidak mempunyai halangan perkawinan menurut Undang-Undang No.1 Tahun 1974"

Sebagaimana telah diuraikan bahwa, itsbat nikah merupakan penetapan dari pernikahan yang dilakukan oleh sepasang suami isteri, yang telah menikah sesuai dengan hukum Islam dengan memenuhi rukun dan syarat pernikahan, sehingga secara hukum fiqih pernikahan itu telah sah.

Dengan melihat uraian Pasal 7 ayat (2) dan (3) KHI telah memberikan kewenangan lebih dari yang diberikan oleh Undang-Undang, baik oleh UUP maupun Undang-Undang Nomor 7 Tahun 1989 tentang Peradilan Agama.

Berdasarkan ketentuan tersebut salah satu dari kelima alasan tersebut dapat menjadi dasar untuk mengajukan permohonan itsbat nikah di Pengadilan Agama, karena ke lima hal tersebut tidak diberlakukan secara kumulatif melainkan secara alternatif. ${ }^{27}$ Dengan melihat uraian Pasal 7 ayat (2) dan ayat (3) KHI, berarti KHI telah memberikan kewenangan lebih dari yang diberikan Undang-Undang, baik UUP maupun Undang-Undang Nomor 7 Tahun 1989 tentang Peradilan Agama mengenai permasalahan itsbat nikah.

Syarat yuridis formil untuk mengajukan itsbat nikah di pengadilan agama di dalam UUP adalah pada Bab XIII Pasal 64 ketentuan peralihan UUP, yaitu untuk perkawinan dan segala sesuatu yang berhubungan dengan perkawinan yang terjadi sebelum Undang-Undang ini

27 Universitas Pembangunan. Skripsi Hukum http://www.library.upnvj.ac.id/pdf/s1hukum08/2047 11001/b1b4.pdf. 28 Maret 2018. 

berlaku, yang dijalankan menurut peraturan-peraturan lama yang sah.

Hal ini sesuai dengan Pasal 7 ayat (2) KHI, yaitu dalam perkawinan tidak dapat dibuktikan dengan akta nikah dapat diajukan itsbat nikahnya ke Pengadilan Agama, dan pada ayat (3) huruf d, yaitu adanya perkawinan yang terjadi sebelum berlakunya UUP.

Dalam hukum acara Peradilan Agama tidak menentukan apa yang harus dimuat dalam surat mengajukan itsbat nikah, sebagai pedoman cara mengajukan gugatan/permohonan, sehingga mengacu pada Hukum Acara Perdata secara umum, yaitu dinyatakan dalam Pasal 8 Nomor 3 Rv. Selain itu, surat gugatan/permohonan harus memuat tiga unsur pokok, antara lain: ${ }^{28}$

a) Identitas para pihak, yang meliputi nama lengkap dengan menyebutkan nama orang tuanya (bin/binti), umur, agama, pekerjaan/jabatan, tempat tinggal yang jelas dan dapat dijangkau pos.

b) Posita/Fundamentum petendi, yang merupakan dalil-dalil konkrit tentang adanya hubungan hukum yang merupakan dasar serta alasan dari pada gugatan/permohonan, terdiri dari dua bagian, yaitu pertama menguraikan tentang kejadian-kejadian atau peristiwa-peristiwa hukum yang harus diuraikan secara kronologis, jelas dan tegas, kedua tentang adanya hubungan hukum yang menjadi dasar yuridis dari

28 Tutiek Retnowati. 2011. Tinjauan Yuridis Penyelesaian Perkawinan siri yang telah diitsbatkan berdasarkan UU No. 1 Tahun 1974. Jurnal Fakultas Hukum. Volume XX No.20. April 2018. Fakultas Hukum Narotama Surabaya . pada tuntutan hak tersebut, yang disebut juga dengan middelen van de eis.

c) Petitum atau tuntutan, yaitu apa yang diminta atau diharapkan agar diputuskan oleh pengadilan melalui hakim, dan petitum ini harus dirumuskan dengan jelas dan tegas.

Dengan mengacu pada persyaratan surat gugatan /pemohon termasuk itsbat nikah pada prinsipnya harus dibuat tertulis oleh Penggugat atau Pemohon atau oleh kuasanya yang sah, akan tetapi bila penggugat/pemohon buta huruf, maka gugatan/pemohon itsbat nikah dapat diajukan secara lisan ke Pengadilan Agama.

Apabila gugatan/permohonan itsbat nikah diajukan secara lisan, maka panitera atas nama ketua Pengadilan Agama membantu untuk membuat catatan yang diterangkan oleh penggugat/pemohon, yang disebut dengan catatan gugatan atau catatan pemohon. Selanjutnya, catatan tersebut dibacakan kembali agar penggugat/pemohon yang buta huruf dimaksud mengerti isinya, kemudian setelah sependapat dengan isi dari catatan penggugat/permohonan tersebut maka penguggat/pemohon membutuhkan cap jempolnya diatas surat gugatan /permohonan tersebut dengan dilegalisasi oleh panitera kepada Pengadilan Agama.

$\mathrm{Ke}$ pengadilan mana gugatan/permohonan itsbat nikah adanya perkawinan dalam rangka penyelesaian perceraian tersebut diajukan sejak berlakunya Undang-Undang Nomor 7 Tahun 1989 tentang Peradilan Agama melalui Pasal 49, Pengadilan Agama berwenang untuk memeriksa, mengadili, 

dan memutus perkara-perkara dalam tingkat pertama antara orang-orang yang beragama Islam di bidang:

a. Perkawinan

b. Kewarisan, wasiat, dan hibah yang dilakukan berdasarkan hukum Islam

c. Wakaf dan Shadaqah

Ada dua cara mengajukan permohonan itsbat nikah yaitu: ${ }^{29}$

1. Dengan cara mengajukan permohonan pengesahan nikah (Voluntair)

Produk hukum Pengadilan Agama terhadap permohonan pengesahan nikah berbentuk penetapan. Oleh karena itu pengesahan nikah yang diajukan secara voluntair, adalah apabila pasangan suami isteri yang perkawinan tidak tercatat itu bersama-sama menghendaki pernikahannya itu dicatatkan di Kantor Urusan Agama Kecamatan yang terlebih dahulu mengajukan permohonan itsbat nikah di pengadilan agama. Mereka bertindak sebagai Pemohon I dan Pemohon II.

2. Dengan cara mengajukan gugatan pengesahan nikah (Kontensius)

Produk hukum Pengadilan Agama terhadap gugatan pengesahan nikah berbentuk putusan. Bila ada kepentingan hukum dengan pihak lain, maka pengesahan nikah tidak bisa diajukan secara voluntair (permohonan) tetapi harus diajukan dalam bentuk gugatan pengesahan nikah. Misalnya anak, wali nikah atau pihak lain yang berkepentingan hukum dengan perkawinan tidak tercatat dan salah satu dari suami isteri dari perkawinan yang tidak tercatat sudah meninggal.

29 Transkripsi Hasil Wawancara dengan Ahmad Musa Hasibuan. Hakim Pengadilan Agama Kelas I A Palembang. Palembang. Jum'at. 27 April 2018.
Tidak demikian halnya dalam permohonan pengesahan nikah secara kontensius, yaitu pemohon melibatkan orang lain sebagai termohon misalnya isteri terdahulu dan atau para ahli waris suami pemohon.

Akibat hukum bagi isteri setelah putusan itsbat nikah Pada putusan Pengadilan Agama Palembang Nomor 0650/Pdt.G/2014/PA.Plg dalam kasus permohonan itsbat nikah yang dikumulasikan dengan gugatan perceraian, penulis menganggap bahwa putusan Hakim sudah tepat. Menimbang, bahwa untuk memenuhi ketentuan pasal 7 ayat (5) Peraturan Mahkamah Agung Republik Indonesia Nomor 01 Tahun 2008 Tentang prosedur Mediasi di Pengadilan Majelis Hakim telah menunda sidang untuk memberi kesempatan kepada Penggugat dan Tergugat menempuh mediasi dengan Mediator Dra. LAILA AMIN, SH, namun berdasarkan hasil laporan Mediator tersebut tanggal 21 Mei 2014, ternyata tidak berhasil.

Gugatan cerai Penggugat didasarkan pada dalil yang pada pokoknya bahwa diantara Penggugat dan Tergugat telah terjadi perselisihan dan pertengkaran yang pada pokoknya antara lain disebabkan masalah ekonomi yang tidak mencukupi, karena Tergugat tidak mempunyai pekerjaan tetap dan puncak ketidak harmonisan rumah tangga Penggugat dan tergugat terjadi pada bulan Agustus 2013 Tergugat cemburu kepada Penggugat, karena Penggugat mempunyai penghasilan sendiri, sedangkan Tergugat tidak mempunyai penghasilan yang tetap dan sejak kejadian tersebut antara Penggugat dan Tergugat tidak ada komunikasi lagi dan dengan kenyataan yang tejadi antara 

Penggugat dan Tergugat tidak serumah lagi, karena Tergugat pergi meninggalkan Penggugat sampai lebih kurang 1 bulan lamanya.

Maka berdasarkan dasar-dasar pertimbangan fakta di persidangan dan berdasarkan keterangan para saksi maka pada hari Rabu tangal 11 Juni 2014 maka Majelis Hakim memutuskan :

1. Menerima dan mengabulkan gugatan untuk seluruhnya;

2. Menyatakan sah perkawinan antara Penggugat dan Tergugat;

3. Menetapkan perkawinan antara Penggugat dan Tergugat putus karena perceraian;

4. Menjatuhkan talak satu bain sughro Tergugat kepada Penggugat;

5. Menetapkan biaya yang timbul dalam perkara ini sesuai hukum yang berlaku.

Setelah perkawinan tidak tercatat tersebut dinyatakan sah melalui proses peradilan di Pengadilan Agama, maka perkara perceraiannya diakhiri dengan putusan. Setelah putusan perkara perceraian dari perkawinan tidak tercatat tersebut telah berkekuatan hukum tetap, maka status suami isteri sebagai duda dan janda mempunyai kepastian hukum dan kedudukannya dapat dibuktikan dengan akta autentik berupa putusan Pengadilan Agama.

Putusnya perceraian suami isteri yang telah dikumulasikan dengan itsbat nikah maka timbul akibat hukum terhadap kedudukan, hak dan kewajiban mantan suami maupun isteri menurut Pasal 41 huruf c UUP yaitu, pengadilan dapat mewajibkan kepada bekas suami untuk memberikan biaya penghidupan dan/atau menentukan sesuatu kewajiban bagi bekas isteri.
Kewajiban mantan suami memberikan nafkah, pakaian, tempat kediaman untuk isteri yang ditalak selama ia masih dalam iddah, bila masa iddah habis maka habis juga kewajibannya. Namun memberi nafkah untuk anak-anaknya berupa belanja untuk memelihara dan keperluan pendidikan anak-anak sesuai dengan kemampuannya tetap wajib sampai anak-anak baligh lagi berakal serta mempunyai penghasilan.

Dengan demikian, status perkawinan tidak tercatat tersebut dinyatakan sah dan akibat hukum dari adanya perkawinan tidak tercatat yang telah dinyatakan sah melalui penetapan pengadilan membawa akibat hukum, yaitu anak-anak yang lahir dari perkawinan tidak tercatat tersebut adalah anak sah, ${ }^{30}$ yang mempunyai hubungan hukum (Perdata) dengan kedua orangtuanya tersebut terhitung sejak perkawinan tidak tercatat tersebut dinyatakan sah oleh Pengadilan Agama.

Hambatan Dalam Proses Pengajuan Permohonan Itsbat Nikah

Dalam pengajuan permohonan itsbat nikah di Pengadilan Agama menurut hasil wawancara dengan Ahmad Musa Hasibuan, selaku Hakim Pengadilan Agama Kelas I A Palembang menjelaskan pada saat datang ke Pengadilan Agama untuk mengajukan permohonan itsbat nikah khususnya di Pengadilan Agama Palembang kendalanya

\footnotetext{
${ }^{30}$ Lihat Pasal 42 Undang-Undang Nomor 1 Tahun 1974 tentang Perkawinan .
} 

adalah identitas pemohon yang tertera pada Kartu Tanda Penduduk berbeda wilayah hukum Pengadilan Agama tempat diajukan pemohon dalam permohonan itsbat nikah, pada asasnya permohonan itu harus sesuai dengan kompetensi relatif ${ }^{31}$, yaitu mengajukan permohonan di Pengadilan Agama wilayah hukum pemohon tinggal. Hal tersebut terjadi dikarenakan ketidaktahuan masyarakat dalam pengajuan permohonan itsbat nikah, sehingga pengajuan permohonan itsbat nikah tidak dapat diterima.

1. Pelaksanaan Putusan

Dengan demikian putusan perkara yang dapat dilakukan eksekusi adalah diktum putusan yang bersifat kondemnatoir, sedangkan putusan yang diktumnya bersifat declatoir dan atau constitutoir seperti dalam permohonan itsbat nikah adanya perkawinan dalam rangka penyelesaian perceraian dapat dikatakan tidak perlu adanya eksekusi. Sehingga dalam pelaksanaan putusan dari dikabulkannya itsbat nikah oleh majelis hakim di Pengadilan Agama, maka dalam hal ini yang dibahas oleh penulis yaitu putusannya menjadi satu kesatuan. Pertama menyatakan bahwa perkawinan antara pemohon dan termohon adalah sah dan putus karena perceraian. Karena dibuat menjadi satu kesatuan supaya tidak ada penyalahgunaan yaitu penyelundupan hukum terhadap permohonan itsbat nikah yang dikumulasikan dengan perceraian. Sehingga status pemohon menjadi jelas dimata hukum yaitu menjadi seorang janda, serta anak-anak yang dilahirkan dari

31 Transkripsi Hasil Wawancara dengan Ahmad Musa Hasibuan. Hakim Pengadilan Agama Kelas I A Palembang. Palembang. Jum'at. 27 April 2018. perkawinan mereka statusnya jelas, serta status secara keperdataan lainnya.

\section{Hambatan dalam proses Pemeriksaan} dan Pengabulan Permohonan Itsbat Nikah

Pada proses pemeriksaan dan pengabulan permohonan itsbat nikah di Pengadilan Agama seringkali mengalami hambatanhambatan, antara lain: ${ }^{32}$

3.1 Pembuktian Dipersidangan Dalam Menghadirkan Saksi

a.Saksi yang mengetahui tentang perkawinan sudah langka.

b.Saksi yang dihadirkan saksi bukan yang sebenarnya.

\subsection{Adanya Penyelundupan Hukum}

Sekarang ini banyak terjadi nikah siri atau tidak tercatat dengan tujuan yang tidak baik, yang merupakan penyelundupan hukum. Salah satunya adalah perkawinan poligami, fenomena yang banyak terjadi saat ini adalah banyaknya praktek poligami dengan berbagai macam alasan dan latar belakang. Kebanyakan praktek poligami itu dilakukan tanpa seizin dari isteri pertama. Padahal seorang suami yang masih terikat perkawinan dengan perempuan lain apabila akan beristeri lebih dari seorang wajib mengajukan permohonan ke Pengadilan Agama setempat sehingga mereka melakukan perkawinan tidak tercatat, padahal faktanya dalam perkawinan siri atau tidak tercatat banyak menimbulkan permasalahan bagi keluarga itu sendiri dikemudian hari mengenai status perkawinan, harta warisan ataupun kebendaan

32 Transkripsi Hasil Wawancara dengan Ahmad Musa Hasibuan. Hakim Pengadilan Agama Kelas I A Palembang. Palembang. Jum'at. 27 April 2018. 

3.3 Dalam Mengajukkan Permohonan Itsbat Nikah Kurang Pihak

Dalam pemeriksaan permohonan itsbat nikah di persidangan yaitu dalam mengajukan permohonan itsbat nikah salah satu pasangan suami isteri sudah meninggal dunia, maka semua ahli waris dijadikan pihak tanpa terkecuali sebagai termohon. Dalam prakteknya hambatan yang dihadapi oleh pemohon yang mengajukan permohonan itsbat nikah yang bersifat kontensius misalnya permohonan untuk pembagian harta waris, para ahli waris terkadang tidak dijadikan pihak, apakah itu salah satu orang tua yang masih hidup, atau salah satu anak ahli waris tidak dijadikan pihak, sehingga permohonan itsbat nikah tidak dapat diterima (ditolak) oleh Majelis Hakim.

\subsection{Pengajuan Itsbat Nikah Yang Perkawinan Tidak Tercatat Tidak Memenuhi Rukun Dan Syarat Dalam Hukum Perkawinan}

Untuk melaksanakan suatu suatu perkawinan menurut Hukum Islam harus memenuhi rukun dan syarat. Rukun dan syarat perkawinan dalam Hukum Islam merupakan hal penting demi terwujudnya suatu ikatan perkawinan antar seorang lelaki dengan seorang perempuan. Rukun perkawinan merupakan faktor penentu bagi sahnya atau tidak sahnya suatu perkawinan. Adapun syarat perkawinan adalah faktorfaktor yang harus dipenuhi oleh para subjek hukum yang merupakan unsur atau bagian dari akad perkawinan.

\subsection{Kurangnya Pengetahuan Masyarakat Tentang Itsbat Nikah}

Kurangnya sosialisasi dan penyuluhanpenyuluhan hukum tentang istbat nikah didalam masyarakat mengakibatkan minimnya pengetahuan masyarakat tentang proses itsbat nikah. Pada Pengadilan Agama hal ini disebabkan karena hilangnya Penyuluhan Hukum karena tidak adanya anggaran untuk menyelenggarakan penyuluhan tersebut.

\section{KESIMPULAN DAN SARAN}

1. Fungsi itsbat nikah dalam memberi perlindungan hukum terhadap isteri yang dinikahi secara tidak tercatat (nikah siri) apabila terjadi perceraian adalah untuk mendapatkan pengakuan dari negara atas perkawinan yang telah dilangsungkan oleh kedua mempelai, anak-anak yang lahir beserta harta bersama, sehingga pernikahannya tersebut berkekuatan hukum, yaitu dengan cara mengajukan itsbat nikah yang dikumulasikan dengan perceraian ke Pengadilan Agama dimana domisili si pemohon berada.

2. Faktor-faktor yang menghambat proses dikabulkannya itsbat nikah dalam kasus perceraian dari perkawinan yang tidak tercatat adalah pada saat akan mengajukan permohonan itsbat nikah pada Pengadilan Agama identitas pemohon bukan wilayah domisili hukum pemohon, pembuktian dipersidangan dalam menghadirkan para saksi-saksi yang mengetahui telah terjadinya perkawinan sangat langka, adanya penyelundupan hukum yang berupa perkawinan poligami tanpa seizin dari isteri terdahulu, dalam mengajukan permohonan itsbat nikah kurang pihak serta pengajuan itsbat nikah yang tidak memenuhi rukun dan syarat dalam hukum perkawinan menjadi faktor yang dapat menghambat perlindungan hukum. Serta kurangnya 

pengetahuan masyarakat tentang adanya Itsbat Nikah sebagai salah satu bentuk perlindungan hukum menjadi salah satu hambatan.

Saran

1. Setelah dikabulkannya permohonan itsbat nikah hendaknya segera melaporkannya ke Kantor Urusan Agama (KUA) setempat untuk merealisasikan hak dan kewajiban yang timbul dari permohonan tersebut sehingga perlindungan dan kepastian hukum dapat segera terlaksana.

2. Pemerintah harusnya lebih pro aktif dalam menggalakan penyuluhan hukum tentang prosedur mengajukan itsbat nikah bagi perkawinan yang tidak tercatat serta mensosialisasikan Lembaga Bantuan Hukum gratis sehingga masyarakat mengetahui dengan jelas tentang hak serta kewajiban mereka. 



\section{DAFTAR PUSTAKA}

\section{BUKU}

Harahap, M. Yahya. 1999. Informasi Materiil Kompilasi Hukum Islam : Memposisikan Abstraksi Hukum Islam dalam Cik Hasan Basri (Ed), Kompilasi Hukum Islam dan Peradilan Agama Dalam Sistem Hukum Nasional, Jakarta : Logos.

Soemiyati. 1997. Hukum Perkawinan Islam dan Undang-Undang Perkawinan, Yogyakarta: Liberty.

Subekti, 1985, Pokok-Pokok Hukum Perdata, Jakarta : PT. Internusa.

Syaifuddin, M. dan Turatmiyah, Sri. 2012. Hukum Perceraian, Jakarta : Sinar Grafika.

Muchsin. 2004. Masa Depan Hukum Islam di Indonesia, Jakarta : BP IBLAM.

Ramulyo, Moh. Idris. 2002.

Hukum Perkawinan Islam,

Suatu Analisis Dari

4Undang-Undang Nomor 1

Tahun 1974 Dan Kompilasi

Hukum Islam. Jakarta :

Bumi Aksara.

KONSTITUSI DAN PERATUTAN
PERUNDANG-UNDANGAN
Instruksi Presiden Nomor 1 Tahun 1991
Tentang Penyebarluasan
Kompilasi Hukum Islam
Undang-Undang Republik Indonesia
Nomor 1 Tahun 1974 Tentang Perkawinan
Amanat Presiden No.
R.02/P.U/VII/1973 tanggal
31 Juli 1973 perihal RUU
tentang Perkawinan.

MAKALAH

Ma'sum, Endang Ali. 2012. Kepastian Hukum Itsbat Nikah, dalam Forum Diskusi Penelitian dilaksanakan oleh Balitbang Diklat Kumdil MA RI, di hotel Le Dian Serang,. 15 Mei.

JURNAL HUKUM

Retnowati, Tutiek. 2011. Tinjauan Yuridis Penyelesaian Perkawinan siri yang telah diitsbatkan berdasarkan UU No. 1 Tahun 1974, Jurnal Fakultas Hukum, Volume XX No.20, April 2018, Fakultas Hukum Narotama Surabaya

\section{WEBSITE}

http://www.academia.edu/3797838/SEJAR AH_HUKUM_PERKAWI NAN_DI_INDONESIA_P ENDAHULUAN , 13 Februari 2018Nawawi Muhammad. Sejarah Hukum Perkawinan di Indonesia Pendahuluan.

http://www.library.upnvj.ac.id/pdf/s1huku m08/204711001/b1b4.pdfU niversitas Pembangunan, Skripsi Hukum. 